\title{
The effects of sow viremia and maternal antibodies in porcine circovirus 2 on viral infection and weight of piglets
}

\author{
[Efeito da viremia da porca e de anticorpos maternos para circovírus suíno 2 \\ na infecção e no peso da leitegada] \\ P.F. Gerber, F.M. Garrocho, Z.I.P. Lobato* \\ Escola de Veterinária - Universidade Federal de Minas Gerais - Belo Horizonte, MG
}

\begin{abstract}
The aim of this study was to characterize the porcine circovirus 2 (PCV2) infections in farrowing sows and to evaluate an association with piglet viremia and weight. Twenty sows and 100 newborn piglets were studied. Colostrum and serum of the sows were obtained on the day of parturition. Milk samples were collected on day 20 postpartum. Blood samples were taken and the piglets were weighed on days 1 , 20, 42, 63 and 84 postpartum. Colostrum, milk and serum were evaluated for PCV2 DNA load. Serum was evaluated for neutralizing antibodies. PCV2 DNA was found in 17/20 serum samples, 14/20 colostrum samples and 11/20 milk samples. On day 1 postpartum $29 \%$ of piglets were viremic. PCV2 viral load ranged from 3.02 to $6.75 \log _{10}$ copies $/ \mathrm{mL}$ considering all sampled days. There was no correlation between sow viremia, antibody levels or PCV2 load in colostrum and piglet viremia on day 1 postpartum. The PCV2 load in colostrum and milk was associated with viremia in piglets from weaning to 84 days postpartum. Piglets' PCV2 viremia and viral load could not be associated with weight throughout this study.
\end{abstract}

Keywords: porcine circovirus 2, colostrum, milk, viral load, weight

\section{RESUMO}

O objetivo deste estudo foi caracterizar o efeito do infecção pelo circovírus suíno 2 (PCV2) em porcas gestantes na viremia e no peso da leitegada. Vinte porcas e 100 leitões recém-nascidos foram acompanhados. Amostras de colostro e soro das porcas foram obtidas no dia do parto. Amostras de leite foram coletadas no dia pós-parto 20. Os leitões foram pesados e tiveram amostras de soro coletadas nos dias um, 20, 42, 63 e 84 pós-parto. Soro, colostro e leite foram testados para carga viral do PCV2. Soro foi avaliado para presença de anticorpos neutralizantes. O DNA do PCV2 foi encontrado em 14 de 20 amostras de colostro e em 11 de 20 amostras de leite. No dia pós-parto 1, 29\% dos leitões foram virêmicos. A carga viral do PCV2 variou 3,02-6,75 log10 cópias / mL, considerando todos os dias amostrados. Não houve correlação entre viremia das porcas e os níveis de anticorpos no soro ou na carga de PCV2 no colostro e na viremia dos leitões com um dia de vida. A carga de PCV2 no colostro e no leite foi associada à viremia em leitões do desmame até 84 dias pós-parto. A carga viral do PCV2 em leitões não foi associada com o peso ao longo deste estudo.

Palavras-chave: circovirus suíno 2, colostro, leite, carga viral, peso

\section{INTRODUCTION}

Porcine circovirus 2 (PCV2) is the etiologic agent of several syndromes collectively known as porcine circovirus-associated diseases
(PCVAD), including postweaning multisystemic wasting syndrome (PMWS), enteritis, respiratory disease, and reproductive failure (Opriessnig et al., 2007). PCV2 is ubiquitous in pigs and typically causes subclinical infections, whereas clinical disease occurs in a small proportion of

Recebido em 4 de julho de 2012

Aceito em 5 de novembro de 2013

*Autor para correspondência (corresponding author)

E-mail: ziplobat@vet.ufmg.br 
farms, and generally takes place as maternally derived antibodies wane in post-weaned pigs, between 7 to 15 weeks of age (Madec et al., 2008).

PCV2 has also been associated with vertical transmission leading to sporadically reproductive failure with increased stillborns and mummified fetuses or, more often, to subclinical infections on live-born piglets at parturition (Madson and Opriessnig, 2011). The prenatal infection with PCV2 alone did not induce PMWS in the postnatal period in experimentally infected fetuses, although coinfections and immunostimulation could be associated with PMWS in the growing pigs (Ha et al., 2008). Recently a study showed a high prevalence of PCV2 viremia $(199 / 499,39 \%)$ in pre-suckle piglets from commercial herds without evidence of PCVAD, indicating that subclinical in utero infections can be a common finding in the field (Shen et al., 2010). However, the significance of this observation in later PCVAD occurrence is still unclear.

The aims of this study was to characterize PCV2 DNA in serum, colostrum and milk of sows, antibody levels in sows, and to evaluate an association between the sow status in farrowing with piglet viremia, weight and neutralizing antibodies from farrowing to growing phase in farrow-to-finish herds.

\section{MATERIALS AND METHODS}

The experimental protocol (089/04) was approved by the Ethics Committee in Animal Experimentation of the Universidade Federal de Minas Gerais, Brazil. Four farrow-to-finish herds (H1 to H4) were included in this study. The characteristics from each herd are summarized in Table 1. H1 had no history of PCVAD while $\mathrm{H} 2$ and $\mathrm{H} 3$ had a history of PCVAD 1.5 years prior to this investigation, but had no clinical signs during the present study. H4 had suggestive clinical signs of PCVAD in pigs at 12 to 17 weeks of age. All sows in the herds were routinely vaccinated against porcine parvovirus, erysipelas, colibacilosis, Clostridium perfringens and Mycoplasma hyopneumonie. The sows in $\mathrm{H} 1$ were not vaccinated against PCV2. Those in $\mathrm{H} 2$, $\mathrm{H} 3$, and $\mathrm{H} 4$ were vaccinated twice with $2 \mathrm{~mL}$ of commercial PCV2 vaccine licensed for breeding animals (Circovac; Merial, Lyon, France) at $30 \mathrm{~d}$ and $15 \mathrm{~d}$ before parturition. None of the herds vaccinated piglets against PCV2.

Table 1. Characteristics and performance of the herds in the year of this study

\begin{tabular}{lllll}
\hline & Herd 1 & Herd 2 & Herd 3 & Herd 4 \\
\hline Number of sows & 450 & 890 & 1200 & 314 \\
PCVAD status & Negative & Negative & Negative & Positive \\
PCV2 sow vaccination & No & Yes & Yes & Yes \\
Colostrum management & No & Yes & Yes & Yes \\
All in -all out with empty time & No & Yes & Yes & No \\
Quarantine & Yes & Yes & Yes & No \\
& & & & \\
Total born & 11.37 & 12.21 & 12.91 & 12.65 \\
Born alive & 10.41 & 11.38 & 11.92 & 11.59 \\
$\%$ farrowing mortality & 7.13 & 5.43 & 5.87 & 5.81 \\
\% nursery mortality & 3.71 & 1.02 & 1.37 & 3.76 \\
\% finishing mortality & 2.95 & 2.28 & 1.71 & 30.96 \\
21 days old piglet weight $(\mathrm{kg})$ & 5.38 & 6.09 & 6.34 & 5.73 \\
63 days old piglet weight $(\mathrm{kg})$ & 21.8 & 24.48 & 26.83 & 20.48 \\
150 days old piglet weight $(\mathrm{kg})$ & 96.9 & 99.91 & 99.42 & 100.78 \\
\hline
\end{tabular}

A total of twenty sows ( 5 sows per herd) with a parity range of 1 to 10 (mean \pm standard deviation 4.21 \pm 3.39 ) were randomly chosen. On the day of parturition, samples of the sows' blood and colostrum were collected. A total of 100 newborn piglets (5 piglets per sow) were randomly ear-tagged. Milk samples were collected on the 20th day postpartum. Blood samples from the piglets were taken by jugular venopuncture on days $1,20,42,63$, and 84 postpartum. All samples were stored $-20^{\circ} \mathrm{C}$ until used. Piglets were weighed on days 20, 42, 63 and 84 and were classified as very low, low or satisfactory in each sample day as follows: day 
20 , very low $<5.5 \mathrm{~kg}$, low $=5.6$ to $6.6 \mathrm{~kg}$, satisfactory $>6.6$; day 42 , very low $<11.0 \mathrm{~kg}$, low 11.0 to $14.0 \mathrm{~kg}$, satisfactory > $14.0 \mathrm{~kg}$; day 63 , very low $<22.0 \mathrm{~kg}$, low $=22.0$ to $23.4 \mathrm{~kg}$, satisfactory $>23.5 \mathrm{~kg}$; day 84 , very low $<37.0 \mathrm{~kg}$, low $=37.0$ to $40.0 \mathrm{~kg}$, satisfactory $>40 \mathrm{~kg}$. Five of the 100 piglets died of causes unrelated to PCV2 between day 1 and 21 postpartum.

The presence of PCV2 DNA was tested in colostrum, milk and serum. The DNA extraction was performed with a Wizard Genomic DNA Purification kit (Promega, Madison, Wisconsin, USA). Quantitative real-time polymerase chain reaction (qPCR) was performed as previously described (McIntosh et al., 2009). Each quantitative real-time PCR reaction was performed using $12.5 \mathrm{~mL}$ of SYBR green reaction mix (SYBR Green Master Mix; Applied Biosystems, Foster City, USA), $150 \mathrm{nM}$ of each primer PCV2, $3 \mathrm{~mL}$ of template, and made up to $25 \mathrm{~mL}$ with sterile water. The reactions were performed in an Applied Biossystems 7500 thermal cycler under universal thermal cycling conditions. The results were recorded as the number of PCV2 copies $\log _{10}$ transformed per millilitre of serum, colostrum or milk.

PCV2 neutralizing antibodies (NA) in serum were tested in serum samples as previously described (Gerber et al., 2012). Briefly, samples were serially diluted 2-fold (1:16 to 1:2048) in complete Dulbecco's Modified Eagle's Medium (DMEM) in 96-well plates. Two hundred median tissue culture infective doses $\left(\mathrm{TCID}_{50}\right)$ of PCV2 were added to each well. After $1 \mathrm{~h}$ of incubation, freshly trypsinized PK15 free cells were added to the samples, and the plates were incubated for $72 \mathrm{~h}$ at $37^{\circ} \mathrm{C}$ in $5 \% \mathrm{CO}_{2}$. The plates were then fixed and incubated for $1 \mathrm{~h}$ at $37^{\circ} \mathrm{C}$ with an antiPCV2 polyclonal serum (VMRD, Pullman,
Washington, USA). The plates were then incubated for $1 \mathrm{~h}$ with protein $\mathrm{G}$ conjugated with peroxidase and stained with a solution of 3-amino-9-diethylcarbazole. The NA titer was established as the reciprocal of the last dilution in which a given sample was able to reduce by $50 \%$ the number of PCV2-infected cells. The equivalent dilutions were $16=4 ; 32=5 ; 64=6$; $128=7 ; 256=8 ; 512=9 ; 1024=10 ;$ and 2048 $=11$. The titers were classified as follows: $<4 \log _{2}=$ negative; 4 to $6 \log _{2}=$ low; 7 to $8 \log _{2}$ $=$ moderate; and $>9 \log _{2}=$ high.

The Shapiro-Wilk test was used to evaluate the normality of the data distribution of the examined variables. The student's t test was used to analyze differences in the weight of each age-group between herds. The nonparametric Kruskal-Wallis test was used to analyze weight categories within each age-group between herds. Spearman's correlation was used to correlate PCV2 viral load with weight of animals in each age-group, sows' PCV2 viral load and antibody levels with piglets' weight, viral load and antibody levels. The results were considered significant at $P<0.05$.

\section{RESULTS}

On the day of parturition all sows had moderate to high PCV2 NA in the serum (mean \pm standard deviation $9.51 \pm 1.01 \log _{2}$ ) and $17(85 \%)$ of the sows were qPCR-positive, with 3.20 to $3.69 \log _{10}$ PCV2 copies/mL of serum (Table 2). Fourteen of $20(70 \%)$ colostrum samples and 11 of $20(55 \%)$ milk samples were PCV2 qPCR positive. There was no significant difference in PCV2 NA mean or in the number of PCV2 DNA positive samples in serum, colostrum or milk between herds. However, sows in H4 had a higher PCV2 load in serum $(P<0.05)$ (Table 2).

Table 2. Number of positive animals for PCV2 DNA in colostrum, milk and serum and neutralizing antibodies to PCV2 in serum of sows on the day of parturition

\begin{tabular}{lllll}
\hline \multicolumn{5}{c}{ Number of positive animals /total number of animals (mean \pm SD) } \\
\hline \multirow{2}{*}{ Herd } & \multicolumn{2}{c}{ PCV2 DNA (PCV2 DNA copies $\left.\log _{10} / \mathrm{ml}\right)$} & PCV2 NA $\left(\log _{2}\right)$ \\
\cline { 2 - 5 } & Colostrum & Milk & Serum & Serum \\
2 & $4 / 5(2.40 \pm 1.41)$ & $3 / 5(1.52 \pm 1.40)$ & $4 / 5(2.80 \pm 1.58) \mathrm{AB}$ & $5 / 5(9.00 \pm 0.70)$ \\
3 & $3 / 5(1.52 \pm 1.24)$ & $3 / 5(1.77 \pm 1.50)$ & $4 / 5(2.67 \pm 1.51) \mathrm{A}$ & $5 / 5(9.40 \pm 0.54)$ \\
4 & $3 / 5(1.71 \pm 1.57)$ & $2 / 5(1.20 \pm 1.66)$ & $4 / 5(2.78 \pm 1.56) \mathrm{AB}$ & $5 / 5(10.21 \pm 0.47)$ \\
\hline
\end{tabular}

Different superscripts within the column indicate significant differences $(P<0.05)$ between groups. 
On day 1 postpartum, PCV2 DNA was detected in the serum of 29 of the 100 piglets (3.34 to $5.05 \log _{10}$ PCV2 copies $/ \mathrm{mL}$ ) (Table 3 ); there were 1 to 3 positive piglets per litter. There was no difference in the number of viremic piglets between the herds. All herds presented the highest number of viremic animals on day 21 postpartum (Table 3). PCV2 viral load ranged from 3.02 to $6.75 \log _{10}$ copies $/ \mathrm{mL}$ in positive animals considering all sampled days.

Table 3. Number of positive animals for PCV2 DNA in the serum of piglets on days 1, 21, 42, 63 and 84 postpartum

\begin{tabular}{cccccc} 
& \multicolumn{5}{c}{ Number of positive animals/total number of animals; PCV2 copies $\log _{10} / \mathrm{mL}$ of serum on day } \\
post-partum $($ mean \pm SD)
\end{tabular}

Different superscripts within the column indicate significant differences $(P<0.05)$ between groups.

There was no correlation between sow viremia, antibody levels or PCV2 load in colostrum and piglet viremia on day 1 postpartum. However, there was a weak correlation between PCV2 viral load in colostrum and milk and PCV2 viral load in piglets' serum on day $21,42,63$ and 84 postpartum $(r=0.18$ to $r=0.26 ; P<0.01)$.
The serological profile of PCV2 neutralizing antibodies from day 1 to 84 postpartum is shown in Table 4. PCV2 NA maternal antibodies declined gradually from day 1 to 63 in all herds, followed by an increase in the mean of PCV2 load on day 42. There was a mild negative correlation between viral load and neutralizing antibodies considering all sample days $(r=-0.41$, $P<0.01)$.

Table 4. Number of positive piglets for neutralizing antibodies to PCV2 on days 1, 21, 42, 63 and 84 postpartum

\begin{tabular}{lccccc}
\multirow{2}{*}{ Herd } & \multicolumn{5}{c}{ Number of positive animals/total number of animals; neutralizing PCV2 antibodies $\log _{2}$ on day } \\
& \multicolumn{5}{c}{ post-partum (mean \pm SD) } \\
\cline { 2 - 5 } & 1 & 20 & 42 & 63 & 84 \\
\hline \multirow{2}{*}{1} & $25 / 25$ & $25 / 25$ & $24 / 25$ & $23 / 25$ & $22 / 25$ \\
& $(11.06 \pm 0.00)$ & $(6.84 \pm 1.38) \mathrm{C}$ & $(5.95 \pm 1.47) \mathrm{B}$ & $(6.20 \pm 2.83)$ & $(7.53 \pm 3.35) \mathrm{AB}$ \\
2 & $25 / 25$ & $22 / 22$ & $22 / 22$ & $22 / 22$ & $22 / 22$ \\
& $(11.06 \pm 0.00)$ & $(9.48 \pm 1.02) \mathrm{A}$ & $(7.69 \pm 0.68) \mathrm{A}$ & $(7.48 \pm 0.66)$ & $(8.23 \pm 1.38) \mathrm{AB}$ \\
3 & $25 / 25$ & $23 / 23$ & $23 / 23$ & $23 / 23$ & $23 / 23$ \\
& $(11.06 \pm 0.00)$ & $(8.52 \pm 0.98) \mathrm{AB}$ & $(7.31 \pm 1.05) \mathrm{A}$ & $(7.31 \pm 0.86)$ & $(6.71 \pm 2.39) \mathrm{B}$ \\
4 & $25 / 25$ & $25 / 25$ & $24 / 25$ & $22 / 25$ & $25 / 25$ \\
& $(10.06 \pm 1.60)$ & $(8.12 \pm 1.60) \mathrm{B}$ & $(6.75 \pm 2.79) \mathrm{AB}$ & $(6.37 \pm 2.26)$ & $(8.62 \pm 2.42) \mathrm{A}$ \\
\hline \multicolumn{7}{l}{ Different superscripts within the column indicate significant differences $(P<0.05)$ between groups. }
\end{tabular}

On days 21 and 42 postpartum there was no difference between the piglets' weight among herds (mean \pm standard deviation $5.91 \pm 1.35$ and $10.55 \pm 2.07 \mathrm{~kg}$, respectively). On days 63 and 84 postpartum the weight mean was significant lower in herds 1 and 4 (mean \pm standard deviation $20.56 \pm 3.77$ and $33.89 \pm 6.80 \mathrm{~kg}$, respectively) than in herds 2 and 3 (mean \pm standard deviation $26.49 \pm 4.05$ and $41.40 \pm 6.41$, respectively; $P<0.05)$. In order to assess the role of PCV2 load on the piglets' weight, the latter was classified as satisfactory, low or very low and the number of viremic piglets and viral load of each category was assessed (Table 5). There was no difference 
between viral load and number of viremic piglets between the weight categories in any sample date (Table 5). There was a moderate correlation between weight at weaning and weight on days 42,63 and 84 postpartum $(r=0.61, r=0.62, r=$
0.57, respectively; $P<0.01$ ), regardless PCV2 viral load or viremia. There was a weak positive correlation between PCV2 viral load and weight among the sample dates $(r=0.22$ to $r=0.27$, $P<0.01)$.

Table 5. Number of PCV2 viremic animals and viral load in the serum of piglets on days 1, 21, 42, 63 and 84 postpartum per weight categories

\begin{tabular}{lcccc}
\hline & \multicolumn{4}{c}{$\begin{array}{c}\text { Number of positive animals/total number of animals; PCV2 copies log10/mL of serum on } \\
\text { day post-partum }(\text { mean } \pm \text { SD) }\end{array}$} \\
\cline { 2 - 5 } Weight & 20 & 42 & 63 & 84 \\
\hline Very low & $32 / 38(2.59 \pm 1.33)$ & $25 / 35(3.20 \pm 2.09)$ & $11 / 33(1.24 \pm 1.73)$ & $15 / 41(1.20 \pm 1.83)$ \\
Low & $25 / 29(2.56 \pm 1.34)$ & $35 / 55(2.84 \pm 2.21)$ & $4 / 14(1.20 \pm 1.83)$ & $7 / 16(1.24 \pm 1.73)$ \\
Satisfactory & $22 / 28(2.60 \pm 1.51)$ & $5 / 5(4.39 \pm 1.08)$ & $28 / 47(1.98 \pm 1.68)$ & $19 / 37(1.98 \pm 1.68)$ \\
\hline
\end{tabular}

\section{DISCUSSION}

The results of the present study show that early PCV2 viremia and viral load in piglets from weaning to the growing phase were not related to weight gain. Herd management practices may have had a major role in piglets' development; since herds 1 and 4, which did not adopt proper hygiene measures, presented the lowest piglets' weight mean throughout the study, regardless the PCVAD status. In addition, herds 2 and 3, which presented the best growth performance and overall lowest mortality rate, had a significantly higher number of viremic animals and higher viral load mean in the growing phase. Indeed, Brunborg et al. (2010) associated errors in management routine with an increase in mortality and a higher incidence of underweight pigs at slaughter even in the periods free from PMWS in a herd. Those data reinforce the multifatorial characteristic of PCVAD and the importance of risk factors related to poor biosecurity and inadequate herd management in disease expression (Madec et al., 2008).

Recently, Shen et al. (2010) found a high prevalence of PCV2 viremia (199/499) and specific anti-PCV2 antibodies in presuckle serum samples (107/499) in herds without evidence of PCVAD. The same study suggests that PCV2 vaccination in sows may reduce intrauterine infection of piglets. Although the present study was not able to test presuckle serum for PCV2 DNA, there was no difference between the number of viremic piglets on day 1 postpartum among sows PCV2-vaccinated or -unvaccinated. The vaccination of sows against PCV2 was not able to prevent in utero infection of piglets, as previously reported (Madson et al., 2009).

Although PCV2 load in colostrum and milk seems to have a mild association with piglets' viral load in serum from weaning to growing phase, no associations between sow PCV2 status and mortality in piglets were found in the present study. Another study has associated sow viremia and low antibody titers at parturition with higher morbidity and mortality rates associated with PMWS in piglets (Calsamiglia et al., 2007). This may be related to the high level of neutralizing antibodies and the high number of viremic sows in our study.

There was evidence that prenatal experimental PCV2 infection did not induce PMWS in the absence of further postnatal co-infection or immunostimulation; however prenatally infected animals had a significantly lower body weight compared to the control group (Ha et al., 2008). In the present study we were not able to associate early PCV2 viremia and low body weight; and it seems that herd management, despite the PCV2 loads in serum, was the most important factor in furthering weight in piglets.

The quantification of PCV2 mean viral load in serum was similar in all herds; no animal had a viral load above the cut off $7 \log _{10} / \mathrm{mL}$ serum considered PCVAD-positive (Olvera et al., 2004). We found a mild negative correlation between PCV2 viral load and neutralizing antibodies level in piglets, in accordance with previous studies (Meerts et al., 2006; Fort et al., 2007). Interestingly, although there was no 
difference between neutralizing antibodies in serum or colostrum of PCV2-vaccinated or unvaccinated sows, NA in piglets declined first in $\mathrm{H} 1$, which did not vaccinate sows against PCV2. This earlier decline in NA was associated with a PCV2 viral load peak in days 21 and 42 postpartum.

\section{CONCLUSIONS}

Although PCV2 sow viremia was not associated with early viremia in piglets, PCV2 load in colostrum and milk was associated with viremia in piglets from weaning to 84 days postpartum. The decline of neutralizing antibodies was associated with an increase in PCV2 viremia. Piglets' PCV2 viremia and viral load was not associated with low weight in this study.

\section{ACKNOWLEDGMENTS}

This work was funded by Fapemig, CNPq and CAPES, Brazil. We thank veterinarians Flávia F. Pinto, Túlia M. Oliveira and José E. Cavalcanti for their assistance with the herds. Dr. Lobato has a research fellowship from CNPq.

\section{REFERENCES}

BRUNBORG, I.M.; FOSSUM, C.; LIUM, B. et al. Dynamics of serum antibodies to and load of porcine circovirus type 2 (PCV2) in pigs in three finishing herds, affected or not by postweaning multisystemic wasting syndrome. Acta Vet. Scand., v.52, p.22, 2010.

CALSAMIGLIA, M.; FRAILE, L.; ESPINAL, A. et al. Sow porcine circovírus type 2 (PCV2) status effect on litter mortality in postweaning multisystemic wasting syndrome (PMWS). Res. Vet. Sci., v.82, p.299-304, 2007.

FORT, M.; OLVERA, A.; SIBILA, M. et al. Detection of neutralizing antibodies in postweaning multisystemic wasting syndrome (PMWS)-affected and non-PMWS-affected pigs. Vet. Microbiol., v.125, p.244-255, 2007.

GERBER, P.F.; GARROCHO, F.M.; LANA, A.M.Q. et al. Fetal infections and antibody profiles in pigs naturally infected with porcine circovirus type 2 (PCV2). Can. J. Vet. Res., v.76, p.38-44, 2012.
HA, Y.; LEE, Y.H.; AHN, K.K. et al. Reproduction of postweaning multisystemic wasting syndrome in pigs by prenatal porcine circovirus 2 infection and postnatal porcine parvovirus infection or immunostimulation. Vet. Pathol., v.45, p.842-848, 2008.

MADEC, F.; ROSE, N.; GRASLAND, B. et al. Postweaning multisystemic wasting syndrome and other PCV2-related problems in pigs: a 12-year experience. Transbound. Emerg. Dis., v.55, p.273-283, 2008.

MADSON, D.M.; PATTERSON, A.R.; RAMAMOORTHY, S. et al. Effect of porcine circovirus type 2 (PCV2) vaccination of the dam on PCV2 replication in utero. Clin. Vacc. Immunol., v.16, p.830-834, 2009.

MADSON, D.M.; OPRIESSNIG, T. Effect of porcine circovirus type 2 (PCV2) infection on reproduction: disease, vertical transmission, diagnostics and vaccination. An. Health Res. Rev., v.12, p.47-65, 2011.

McKEOWN, N.E.; OPRIESSNIG, T.; THOMAS, P. et al. Effect of porcine circovírus type 2 (PCV2) maternal antibodies on experimental infection of piglets with PCV2. Clin. Diagn. Lab. Immunol., v.12, p.1347-1351, 2005.

McINTOSH, K.A.; TUMBER, A.; HARDING, J.C.S. et al. Development and validation of a SYBR green real-time PCR for the quantification of porcine circovírus type 2 in serum, buffy coat, feces, and multiple tissues. Vet. Microbiol., v.133, p.23-33, 2009.

MEERTS, P.; MISINZO, G.; LEFEBVRE, D. et al. Correlation between the presence of neutralizing antibodies against porcine circovírus 2 (PCV2) and protection against replication of the virus and development of PCV-2-associated disease. BMC Vet. Res., v.6, p.1-11, 2006.

OLVERA, A.; SIBILA, M.; CALSAMIGLIA, M. et al. Comparison of porcine circovirus type 2 load in serum quantified by a real time PCR in postweaning multisystemic wasting syndrome and porcine dermatitis and nephropathy syndrome naturally affected pigs. J. Virol. Methods, v.117, p.75-80, 2004.

OPRIESSNIG, T.; MENG, X.J.; HALBUR, P.G. Porcine circovirus type2-associated disease: update on current terminology, clinical manifestations, pathogenesis, diagnosis, and intervention strategies. $J$. Vet. Diagn. Invest., v.19, p.591-615, 2007.

SHEN, H.; WANG, C.; MADSON, D.M.; OPRIESSNIG, T. High prevalence of porcine circovirus viremia in newborn piglets in five clinically normal swine breeding herds in North America. Prev. Vet. Med.. v.97, p.228-236, 2010. 